\title{
Millennium Development Goals, MDG'S; Case of Kosovo
}

\author{
Jona Hoxhaj \\ Economics Department, Epoka University, Tirana/Albania \\ jhoxhaj10@epoka.edu.al
}

Dren Bllaci

Banking and Finance Department, Epoka University, Tirana/ Albania

dbllaci10@epoka.edu.al

\author{
Mergleda Hodo \\ Research Assistant at Economics Department, Epoka University, Tirana/Albania \\ mhodo@epoka.edu.al \\ Elena Pici \\ Economics Department, Epoka University, Tirana/Albania \\ epici10@epoka.edu.al

\section{Dr. Eglantina Hysa} \\ Lecturer at Economics Department, Epoka University, Tirana/Albania \\ ehysa@epoka.edu.al
}

\section{Doi:10.5901/mjss.2014.v5n14p123}

\section{Abstract}

The Millennium Development Goals, present in the UN Millennium Declaration 2000, are a set of goals to reduce poverty, disease, and deprivation of the world's poorest people This paper examines the Development and increscent that Millennium Development goals have lived in a transition country like Kosovo, which is one of the less developed countries in Europe. Furthermore, Kosovo is one of the ancient lands in Balkan passing through many wars and difficulties in achieving growth and prosperity, international presence and effect in all the institutions and government have helped Kosovo to increase the overall economical, political and social life. MDG's are becoming a very important part of changing the standard of living in many of the countries in the world, where living conditions are not in an acceptable position. Also, it critically evaluates each of 8 MDG's and the improvement that they have achieved during these post war years, even though Kosovo is not officially part of MDG's Agreement that all the states have signed.

Keywords: MDG's, Kosovo, Development, Achievement, International institutions

\section{Introduction}

Kosovo is the smallest country in Balkans, pretending to be the most ancient one, but the last one to be developed and integrated in European Union. Republic of Kosovo which declared its independence on $17^{\text {th }}$ of February in 2008, is one of the poorest countries in European continent with the poverty rate of $29.7 \%$. Kosovo can consider the declaration of independence, the improvement of economic situation and transition to open economy as important steps toward progress but it still remains the poorest country in Europe with big challenges to overcome.

In Global Millennium Summit held on $20^{\text {th }}$ of September 2000 in New York, Kosovo did not take place because of not having the status of a state and was being administered by UNMIK.

Millennium Developments goals have a very clear cut objective, to seriously fight against the global challenges of $21^{\text {st }}$ century. This is a commitment for all the countries of the world without exclusion of the developed countries, because united fighting becomes easier. 
Kosovo is working toward the achievement of this goals even though it has not officially signed the agreement, different reports conclude that progress is made in some of the goals such gender parity and education but goals related with health are not going alongside with improvements worldwide

Millennium Development Goals are eight and one extra goal UNDP Kosovo has made for Kosovo as country in transition and after wear country, each of them is committed for one important issue in increasing welfare.

Goal 1: Eradicate Extreme Poverty and Reduce Relative Poverty

Goal 2: Achieve Universal Primary Education and Improve the Quality of Education

Goal 3: Promote Gender Equality and Empower Women

Goal 4: Reduce Child Mortality

Goal 5: Reduce Maternal Mortality

Goal 6: Combat HIVIAIDS and Tuberculosis

Goal 7: Ensure Environmental Sustainability

Goal 8: Develop a Global Partnership for Development

Goal 9: Building Good Governance towards European Integration

\section{Get to Know Kosovo...}

Kosovo is the smallest country in Balkans, pretending to be the most ancient one, but the last one to be developed and integrated in European Union. Kosovo is a land surrounded by mountains of Sharr, Kopaonik and Albanian Alps. Kosovo is rich country with resources of lignite, lead, nickel, zinc and other minerals. This was the reason of many threats that Kosovo lived during the past; the north of Kosovo is mineral rich and neighbors aware of this, always tried to capture the moment and use this natural resources to increase their wealth as Kosovo did not have the resources to put this minerals into usage for industrial development.

Republic of Kosovo which declared its independence on $17^{\text {th }}$ of February in 2008, is one of the poorest countries in European continent with the poverty rate of $29.7 \%$ (2nd Report for Kosovo, 2004). With the youngest population in the Europe it faces an unemployment rate of young people $60.2 \%$ and unemployment rate of the population $35.1 \%$. (2nd Report for Kosovo, 2004). The main reasons behind it is the poor economy dependent on the remittances entering Kosovo from Diaspora.

Population of Kosovo is multiethnic, which also is symbolized in the flag. As the flag is with starts each representing one of the minorities and one of them representing Albanians that are the majority of population composing 92\% of total, Serbs 4\%, and other minorities like Bosnians, Turks, Egyptian, Roman and Ashkali. (2nd Report for Kosovo, 2004)

After the war, can be considered that Kosovo made significant improvements. As the economy and social life was totally collapsed during the 1990s and the years before when Serbians were ruling this country and not caring about the social and economical condition of this land. After 1999, the end of the war, was a new beginning for the economy of Kosovo, as new businesses were opened and many foreign investments were established. About the security and social life, European Union and US gave the needed help to get up on its feet. But still it is not totally independent state as it is controlled by EULEX not directly but influencing a lot on governing of the state.

Kosovo can consider the declaration of independence, the improvement of economic situation and transition to open economy as important steps toward progress but it still remains the poorest country in Europe with big challenges to overcome. Like high poverty, the dependence on remittances and unemployment of the youth, this is an opportunity that could be used as factor of production.

\section{Millennium Development Goals, Kosovo}

In Global Millennium Summit held on $20^{\text {th }}$ of September 2000 in New York, Kosovo did not take place because of not having the status of a state and was being administered by UNMIK. As Kosovo did not have a seat in Global Summit, Government of Kosovo do not have obligation to reach the fulfillment of MDG's by 2015.

Kosovo is a country that should not be left behind in this topic, MDG's are important to be committed as the quality of life and economic, political and social improvement are not satisfactory. So on $17^{\text {th }}$ October 2008 Assembly of Kosovo managed to reached an agreement, to be part of UN Millennium Declaration, making Kosovo part of the commitment that worldwide countries signed to reach the MDG's by 2015. MDG's are a pathway that worldwide countries use in order to improve the life of people in need by using all their efforts to make Earth a better place to live for everybody.

Kosovo is working toward the achievement of this goals, different reports conclude that progress is made in some 
of the goals such gender parity and education but goals related with health are not going alongside with improvements worldwide. In order to fasten the development of Kosovo and achievement of goals toward improvement of populations lifestyle, Government should urgently increase the quality of data collection. Kosovo is facing a huge challenge in capacity to gather data and have statistical tracking trustful and professional, improvement of Statistical Office of Kosovo (SOK) is a must.

Time is passing and the deadline is closer and closer, Kosovo's institutions, Heads and all the population that is able to help on achieving the goals, should be united to work toward progress of the countries living environment. And achieve the agreement that was signed by 2015 in order to have qualitative life and less risky environment for future generations, working together for environmental sustainability.

\section{The Big Effect of Each MDG in Kosovo}

MDG's can be achieved by being united and working together with inner actors and external actors for one objective, help can be offered by debts, aids and support of rich countries.

The present picture of Kosovo's economic, political and social situation is not bad in comparing it with the after war period. It has have lived tremendous progress in every field, but it still has huge gaps in the quality of life, health and environmental issues. So the challenges to meet MDG's are very big obstacles to be passed which need a huge concentrated work on each of them.

Millennium Developments goals have a very clear cut objective, to seriously fight against the global challenges of $21^{\text {st }}$ century. This is a commitment for all the countries of the world without exclusion of the developed countries, because united fighting becomes easier.

"The Millennium Declaration laid out a vision for a world: without extreme poverty and hunger; with education for all; with equality between women and men; where mothers and children are provided with adequate healthcare ; where people are no longer prone to transmittable diseases; when world's inhabitants cherish a healthy and a common destiny ;where the global community works together to further these aims." (Report, 2010, p. 6) These are the main aims that the MDG's would achieve in the end of 2015 if countries complete their commitments.

Millennium Development Goals are eight, each of them is committed for one important issue in increasing welfare.

\subsection{Eradicate extreme poverty and hunger}

The table below shows some statistics in accordance with three main national targets for achieving the first MDG. Which is not so hope giving as the numbers, show very low employment and high poverty rates.

Poverty is the biggest challenge for Kosovo, as the numbers are showing very high rate of people living without a shelter or without a euro per day to eat and protect themselves. This is supported with high rate of unemployment. The poverty rate cannot be fully reduced without a proper employment and productive laws which will be implemented in order to decrease the number of unemployment and help economic welfare of the country.

\begin{tabular}{|l|l|l|}
\hline Target 1: Reduce extreme poverty by half & -Less than 0.94 Euro per day & $-16.7 \%$ \\
\hline Target 2: Reduce the unemployment rate to 25 \% $\%$ & $\begin{array}{l}\text { Unemployment rate } \\
\text {-Women, Youth }\end{array}$ & $-45 \%$ \\
\hline Target 3: Reduce huger by half & $\begin{array}{l}\text { Prevalence of underweight children } \\
\text { under-five years of age }\end{array}$ & $-59.5 \%, 73 \%$ \\
\hline
\end{tabular}

\subsection{Achieve Universal Primary Education}

Target 4: Is to increase the number of children going to school, girls, children with difficult environment of living and minorities living in Kosovo are compulsory to finish 9 years of Primary education free and with good quality provided by Government.

The share of GDP spent on education will be increased in order to have a progress in quality of education. The spending on education is a new beginning for Kosovo, as education system have started to improve after war, in 1989 Kosovars were excluded from official education system by Serbian regime. Than in this period started education for kosovars informally, people left their houses to be schools for students in order not to lose the Albanian education and culture, this was supported with remittances from Diaspora. This system lasted till years 1999 when war started, and was 
characterized by a low quality of education.

Education even thought is seen as one of the most improving sectors in Kosovo, it stills has many challenges to overcome in the quality of education and decreasing the gap between girls and boys ratio going to school, especially in rural areas.

\subsection{Promote Gender Equality and Empower Women}

Target 5: Gender inequality should be eliminated by year 2015 in all the levels of education, payment of men and women should be equal for performing the same tasks and the number of women represented in national parliament should be $31 \%$ of the total number.

Even though many key positions such as President of KOSOVO Mrs. Atifete Jahjaga are owned by women in Kosovo still they are in disadvantage to men in terms of wage, education, participation and public and opportunity to make their own choices.

\subsection{Reduce Child Mortality}

Target 6: Is to reduce the child mortality under five years old by two third as this number is high because of very low quality of health system in Kosovo. Progress is very difficult because of not so much importance given to health by government and not giving proper proportion from GDP to health system. Data collection is another difficult about this target, as the data management is not a industry in progress.

\subsection{Improve Maternal Health}

Target 7: To decrease the maternal death by three quarts, by decreasing number of mothers that are dead during the birth and also increase the number of mothers that continuously take care of their pregnancy.

The main problems remaining as the challenges for future in Kosovo, is to invest more on data quality as from 2003 there are no available data to conclude the trend of deaths of mothers. Government is dividing low proportion of spending for health of babies and mothers. The low education level of population also makes a gap of knowledge about the health and caring needed for women during pregnancy.

Target 8: Is to ensure access to reproductive health, $63.3 \%$ is ensuring it with contraceptive prevalence (Report, 2010) and antenatal coverage care is low in between 1-4 visits.

\subsection{Combat HIV/AIDS and Tuberculoses}

Target 10: Prevent the spread of HIVIAIDS is another important national task in Kosovo, which aims to prevent HIVIAIDS to be spread over larger number of population. Even though the total number of people infected is not high, the possibility of being infected is high and the factors that risk infection are high. Population is very young, unemployment remains in a high level, people using drugs are increasing and the number people coming from outside in Kosovo is increasing and this makes prevention of HIVIAIDS more difficult as you may not control the sex industry that is increasing day by day.

Target 11: Prevent Tuberculoses by 2015, which is showing a positive trend, in decreasing the number of people infected. (Factsheet, 2010) But what the challenge in this sector is because of lack of evidence about the strategies to prevent TBC, not many funds that help people be treated and also no technical capabilities in Kosovar Hospitals for adequate treatments.

\subsection{Ensure Environmental Sustainability}

Target 12: Is to prevent the loose of forests and degradation of forest by fuel wood, illegal cutting of trees, fire etc. The plan is to have $10 \%$ of the lands protected by law which will meet the needs of citizens of Kosovo.

Target 13: By 2015, people in Kosovo should have access to safe drinking water, which is a very important issue because the pollution effects the water. More than $30 \%$ of population is covering individually the water supply.

Kosovo's environmental legislation is improving in accordance with EU laws, but the implementation is not satisfactory and the environmental issue is worrying about Kosovo.

Challenges are difficult to be overcome as environment is not a priority, lack of infrastructure of water is an issue, 
no management in protection of forests and other areas and the implementation of laws is not being considered important by citizens.

\subsection{Develop a Global Partnership for Development}

The last 2 national targets are to complete trading and financial system based on rules without discrimination, predictions and with open market for operations. The assistance of developed countries is very crucial in Kosovo's economic development, as they support and help its economy to pass the challenges of after war country and make the balance in trading.

Technological improvements have arrived also in Kosovo; it has a high technological approach especially in urban areas which continuously has an increasing trend and also mobile telephones have are wide spread.

\subsection{Building good governance towards European Integration}

This MDG is not in accordance with the 8 others which are worldwide countries goals, it has a special statue for a country like Kosovo which is not a stable governed country. This goal aims efficient, effective and transparent governance in accordance with EU standard. Also this goal is concerned to have a good governed system of justice and security system to ensure better public safety.

Part of this goal is the transparency of Kosovos's institutions toward NGO's, Media and Society, which is part of good governance and implementation of a law existing from 2009.

\section{Conclusion}

Although Kosovo has improved a lot after war, Kosovor society continues to face serious and persisting problems that reflect the challenges that have to be faced for it to meet all the MDGs by 2015.

Income poverty is widespread, very large proportion of population could fall into High poverty as they are in the border of poverty, Kosovor society continues to have very big obstacles to overcome to achieve the growth and prosperity needed for basic standard of living and integration in European Union and other international institutions.

Education attainment indexes do show an improvement, which in turn is reflected in the slight increase in Kosovo's Human Development Index (HDI) and education level which are the main pillars toward improvement.

The World Bank (WB) Poverty Assessment report shows that Kosovo, with an annual average growth rate of two per cent, is likely to meet MDG 2, on Education, and MDG 6, on HIVIAIDS. The current situation with data gathering makes it difficult to estimate exactly whether MDG 5, on Maternal Mortality, will be met.

The policies that have been targeted for achieving growth rates of about five to seven per cent during the period 2009-2015 will create the space for many of the concerns related to the MDGs formulated for Kosovo to be addressed.

The implementation of the EU Partnership Plan is seen as the key requisite for becoming a full member of the European Union. This implies that a framework of principles and standards must be established for Kosovar society to be developed along the lines of EU models.

\section{References}

$2^{\text {nd }}$ Report for Kosovo, M. (2004). UNDP. Retrieved from: http://www.undp.org/content/kosovo/en/home/countryinfo/ Factsheet, U. (2010). Retrieved from: http://www.undg.org/docs/12345/Kosovo---MDG-Factsheet-2010.pdf

Report, U.F. (2010). UNDP. Retrieved 01/07/2014 from: http://www.undg.org/docs/12345/Kosovo---MDG-Factsheet-2010.pdf

UNECE Report on achieving the Millenium Development Goals in Europe an d Central Asia, 2012. Retrieved from: http://www.unece.org /fileadmin/DAM/publications/oes/UNECE_MDG_Report_2012.pdf UNDP. (2007). Millenium Development Goals. Retrieved January 2014 UNDP. (2013). Human Development Index. Retrieved January 2014 UNICEF INSTITUTE of STATISTICS (2011). Retrieved January 2014 Vasili, P. (2010, 09 28). Important steps in improving mothers and children's health. (B. Sot, Interviewer) 